\title{
Transformation of Industrial Heritage - an Example of Tourism Industry Development in the Ruhr Area (Germany)
}

\author{
Sonja Ćopić ${ }^{A}$, Jasmina Đorđević ${ }^{A}$, Tin Lukić ${ }^{A}$, Vladimir StojanovićA ${ }^{A}$, Smiljana Đukičin ${ }^{A}$, \\ Snežana Besermenji ${ }^{A}$, Igor Stamenković ${ }^{A}$, Aleksandar Tumarić ${ }^{B}$ \\ Received: July 12, 2014 | Revised: July 23, 2014 | Accepted: August 4, 2014
}

\begin{abstract}
Industrial heritage represents a specific type of heritage provided by human societes which emerged as a product of industrialization when certain objects were abandoned. Environmentalists and people employed in the tourism industry implement the idea of revitalization on this locations and give new functions to abandoned factories, which is crucial for their later development. There are many industrial zones where tourism can be promoted as a useful instrument of regional restructuring and economic development. Thus, the transformation of industrial heritage in the Rhur area (Germany) is presented in this study, where significant structural changes occurred due to the decline of the mining and metallurgical industry. Key sites used as an example of this transformation of industrial heritage into tourist attractions are located in the central part of the Ruhr area, stretching across the Emscher park. The development effects (environmental, economic, socio-cultural) of industrial heritage tourism and their implementation through certain recultivation procedures within the Ruhr area are also discussed in the paper. All this stand as a good example of sustainable development, where tourism served as an instrument of revitalization and conservation of industrial heritage. This positive approach and experience from Germany could be applied to similar areas and regions across European continent.
\end{abstract}

Key words: Industrial heritage, Ruhr, industrial heritage tourism, Germany, tourism industry

\section{Introduction}

\section{Tourism and Geospace}

Geospace as a significant resource is fairly limited, and tourism is constantly influencing its transformation. As an integrative part of a general system, it is consisted of several subsystems such as: natural, economic, social, communicational, political etc. (Maksin, Mićić, 2008).
Urban spaces include industrial heritage, which has an important potential in tourism development. Historical environment, architecture, and in recent times industrial past, attract increasing number of tourists, which directly affects tourism industry not only on local, but also on national and regional level.

A highly specialized and technologically well equipped industry requests a well developed service sector which belongs to tertiary human activities and

\footnotetext{
A University of Novi Sad, Faculty of Sciences, Department of Geography, Tourism and Hotel Management, Trg Dositeja Obradovića 3, 21000 Novi Sad, Serbia

B University of Novi Sad, Department of History, Faculty of Philosophy, Dr Zoran Đinđić 2, 21000 Novi Sad, Serbia

* Corresponding author: sonjacopic@gmail.com
} 
whose increase is reported in all developed countries (Rabvar, et al., 2005).

\section{Concept of industrial heritage and industrial heritage tourism}

Industrial heritage is a specific type of heritage provided by human societes which emerged as a product of industrialization i.e. as a byproduct of deindustrialization of society, when certain objects were abandoned (Cho, Shin, 2014; Garača, et al., 2014; Jahić, et al., 2014). Industrial heritage location may consist of one building, a complex of buildings, or even a group of locations which comprise several kilometers long tourist route (Trettin, et al., 2011). One of the common expressions used to describe this kind of heritage is 'landscapes of nostalgia' (Halewood, Hannam, 2001; Xie, 2006).

Environmentalists and people employed in the tourism industry implement the idea of revitalization on this locations and give new functions to abandoned factories, which is crucial for their later development. There are many industrial zones where tourism can be promoted as a useful instrument of regional restructuring and economic development (Edwards, Llurdes, 1996).

Tourism represents powerful and effective means for preservation of heritage and reconstruction of 'landscapes of nostalgia'. Industrial heritage tourism refers to development of tourist activities on anthropogenic locations, buildings and sites which incurred with industrial processes of earlier periods (Edwards, Llurdes, 1996). The development of this form of tourism creates opportunities for: 1) raising awareness of historical processes and increase in tourist inflow, 2) strengthening local identity and creating new centers of urban life, 3) promoting a better image of the region in order to attract new investors and 4) adaptation and preparation of buildings for new commercial and cultural purposes (Trettin, et al., 2011).

Industrial heritage tourism has become an important social and economic phenomenon, which highlights the importance of old industries and strengthens local identity by inciting the process of localization in contrast to globalization (Mitchneck, 1998). Therefore, industrial heritage tourism is new exciting combination of instruments of government for improvement of regional identity and elimination of prejudice about decaying industrial zones. It is often denoted as a medium for reinforcing the effect of economic restructuring in urban areas and for emphasis of tourism importance in cities and regions (Hospers, 2002).

The concept of industrial heritage restructuring and industrial tourism development has shown significant potential and over the course of time has evolved from local and regional to continental level, and has a great opportunity to become a global trend. The positive experiences of Western countries (Germany, Great Britain, USA etc.) can be used as a pattern for developing countries that have similar issues (e.g. Jahić, et al., 2014; Petrović, 2013; Đukičin, et al., 2011, 2014).

\section{Study area}

\section{Ruhr region in Germany - general characteristics}

Ruhr (Ruhrgebiet) is an urban area in the German federal state of North Rhine Westphalia (Fig.1). With its 5.5 million people in the area of 4,400 square kilometers, the region is also one of Europe's most densely populated conurbations. The region is dominated by four rivers: the Rhine, Emscher, Lippe and Ruhr. These rivers gave their name to three zones, of the four zones that make up the cities and towns of the Ruhr: Ruhr zone (Verden, Hattingen, Witten, Hagen and Schwerte), Emscher zone (Oberhausen, Bottrop, Gelsenkirchen and Herne) and Lippe zone (Wesel, Dorsten, Marl, Lünen and Hamm). The industrial center of the Ruhr is located between the zones of Emscher and Lippe. This is Helveg zone, named after centuries-old route for transport and trade, whose existence dates back to hanseatic period. All towns, cities and their municipalities comprise Union of Local Authorities of the Ruhr (Kommunalverband Ruhrgebiet), with the center in Essen (Hospers, 2004).

Through the centre of the Ruhr there is a part of the loess belt that extends across Germany from west to east. This loess belt has underlain some of Germany's richest agricultural regions. Geologically, the region is defined by coal-bearing layers from the upper Carboniferous period. The coal seams reach the surface in a strip along the Ruhr River and dip downward to the north. Beneath the Lippe River, the coal seams lie at a depth between 600 to 800 meters. The thickness of the coal layers ranges from one to three meters (three to ten feet). This geological feature played a decisive role in the development of coal mining industry in the Ruhr area (Kretschmann, 2013).

\section{History of industrial development of the region}

Today's scenic appearance of the Ruhr is barely 150 years old. At the end of the 18th century, this was still an agricultural area. Although coal was extracted in the Ruhr valley since the 14th century for fueling, forging and casting, mining was still relatively unimportant. Beginning of the industrial revolution was a prerequisite for the expansion of mining in the Ruhr area in the 19th century. Coal mined in Ruhr Valley was suitable for coking, and as such has created the basis for the production of iron and steel. The industrialization of Ruhr also marked the beginning 


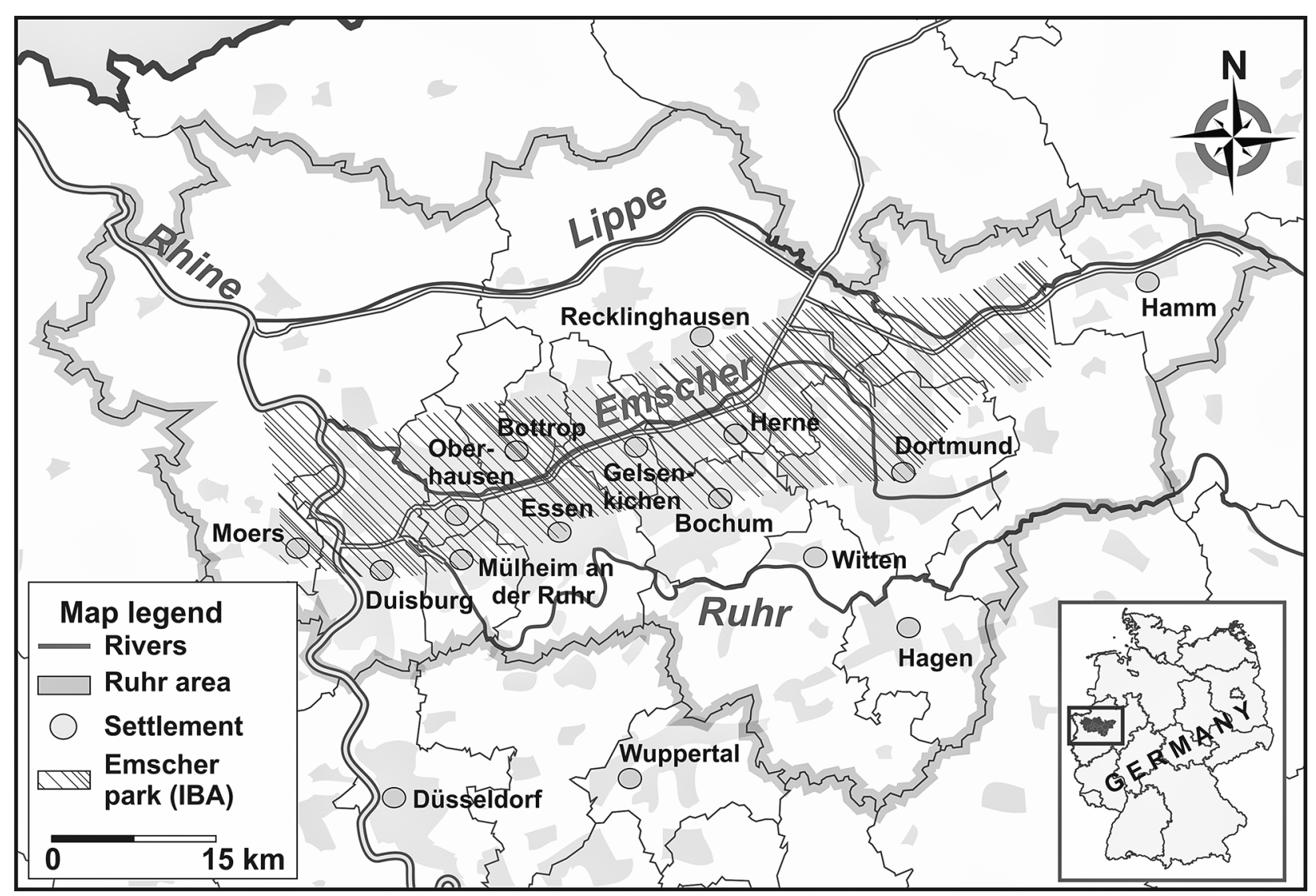

Figure 1. Ruhr area with highlighted position of the Emscher park (IBA)

of extensive traffic connections in the region such as roads, railways and canals. The 'Black Gold' also left its mark on the landscape. For a short period of time the old rural structures were replaced by a complex of collieries, steel mills, coking plants and factories. Supported by progressive Prussian economic policies, after 1850 an enormous industrial boom in the Ruhrgebeit set in. People from all over Germany came to the area looking for work. Between 1850 and 1925 the population rose from 400000 to 3800000 . After the two World Wars, in which many industrial sites were destroyed, it was predominantly Ruhr region that contributed to Germany's 'economic miracle' in the 1950s. In 1956 the mining industry reached its peak: in that year $124600 \mathrm{t}$ of coal were produced, offering work to nearly half a million of people. In 1958, however, the coal-mining crisis started, which put a definitive break on employment in the Ruhr. Cheap imports from countries such as the USA and competition from substitutes for coal (crude oil, natural gas) resulted in the closing of many mines and drastic job losses (Hospers, 2004).

\section{Examples of transformation of industrial heritage of the Ruhr into tourist attractions}

Germany has more projects utilizing natural potentials than other Central European countries, and also best scores regarding innovativeness and sustaina- bility. This is a result of the better framework conditions (state support, larger development areas available, greater environmental awareness) (Marot, Harfst, 2012). Any utilization of mining and post-mining potentials requires cooperation and coordination of several actors in order to establish good and coherent projects (Fischer, Stranz, 2011).

Ruhr area had to undergo significant structural changes due to the decline of the mining and metallurgical industry. During the last three decades it has become a common practice incitement of socio - economic transition in the old industrialized locations, in the context of urban renewal, the development of new forms of urban tourism based on culture and events. Additional attempt represents the conversion of closed factories in places of heritage in order to increase the attractiveness of the destination and to create new opportunities for entrepreneurial activities in the field of tourism and services (Hospers, 2004).

\section{Emscher park}

Emscher Park is located in the central part of the Ruhr area (Figure 1). It stretches around the eponymous river, and includes the cities of Duisburg, Oberhausen, Mülheim, Bottrop, Essen, Bochum, Dortmund and others. The extensive mining in the area had created the danger of subsidence, so rather than install underground sewers that might be breached, authorities 
had redirected and canalized the Emscher River creating, in essence, an open sewer carrying both industrial and human waste (LaBelle, 2001).

To address the serious problem of pollution of the river, the government of North Rhine - Westphalia initiated the IBA program (International Building Exhibition). This ten-year program (1989-1999) was focused on the sub-region around the river Emscher. IBA project was aimed at fostering urban economic, social and ecological restructuring of the old industrialized areas. Therefore, the government of North Rhine - Westphalia established a planning company. The company has launched about 120 individual projects (covering an area of over 800 square kilometers), including the protection and conservation of industrial heritage sites (Hospers, 2004).

The main goal of the IBA project was cleaning of the river Emscher. Underground sewers were made and process of renaturalization of the river began. Another important objective of the project was the creation of a regional park in places where formerly stood industry and old slag heaps. Several thematic tourist driving and biking routes were created, including the 'Route of Industrial Culture' which includes routes with themes such as the 'Route of Industry and Nature'. These routes serve several purposes: to create and improve green infrastructure; provide more recreational opportunities; appeal to tourists; and increase the understanding of the region's heritage among local residents as well as visitors. The creation of a landscape park Emscher has been used to drive the restoration of one of the most degraded landscapes in Europe. It has become a symbol as well as a stimulus for urban, economic, social, and environmental change. (LaBelle, 2001).

Today, the most famous tourist attractions of Emscher Park include: Gasometer in Oberhausen, Zollverein Coal Mine Industrial Complex in Essen, Industrial Landscape Park Duisburg-Nord, artificial hills - tips, bike paths, etc.

\section{Gasometer in Oberhausen}

Oberhausen is a city in the Ruhr area and within the Emscher Park (Figure 1). The Gasometer in this city that has been used for storage of gas produced by the blast furnaces was shut down in 1988. Having lost its original purpose Gasometer got a new purpose within the IBA project - it was converted into exhibition hall. Conversion took place during the years 1993/94. Below the former gas-pressure disc there is a circular room with an area of more than 3000 square meters which is used as an exhibition space. Two steel staircases lead up onto the disc in the middle of which a raised stage with a diameter of $20 \mathrm{~m}$ was installed. Parts of the supporting structure became a stand with 500 seats. The ceiling was turned into a rosette consisting of light panels that change colors. Panorama elevators lead up onto the roof of the Gasometer. From up there, a unique panoramic view of the whole of the western Ruhr can be enjoyed which, during clear weather, extends over 35 kilometers. To date, over 3 million tourists visited Gasometer which has become a symbol of Oberhausen (Figure 2A) (http:// www.gasometer.de/en/).

\section{Zollverein coal mine industrial complex}

Zollverein Colliery is located in the city of Essen (Figure 1). Declared a World Heritage Site by UNESCO in 2001 it is known as the most beautiful mine in the world . Colliery was opened in 1932 and it was one of the most famous symbols of the mining industry in Germany until it was closed in 1986 . Since IBA project started it has become one of the focal points of 'Route of Industrial Heritage' (Prossek, 2006). The complex spreads over 100 hectares and consists of three parts: Shaft XII, Shafts $1 / 2 / 8$ and Coking Plant. Zollverein attracts large numbers of tourists, according to some estimates around 1500 ooo visitors a year (Prossek, 2006). Once the largest colliery in Europe today combines culture, gastronomy, design, architecture and handicrafts. Buildings of the complex were built in the Bauhaus style (LaBelle, 2001). The symbol of the whole complex is a pithead tower at the entrance to the shaft XII (Figure $2 \mathrm{~B}$ ).

The major attractions of the Zollverein complex include: The Ruhr Museum, the Portal of Industrial Heritage, Zollverein memorial trail, Palace of Projects (formerly salt storage, but now building with 16 rooms and 65 projects that represent the utopias of our time), Sun Wheel (Ferris wheel on solar power, which offers view of the entire Zollverein complex and city of Essen), an installation which is a swimming pool and also a work of art, ice rink, etc.

Metropole Ruhr was chosen as Europe's Cultural Capital in 2010 alongside Istanbul in Turkey and Pecs in Hungary, which contributed to number of tourists who visited Zollverein - 2.2 million, an all time high (Lane, et al., 2013).

\section{Industrial landscape park Duisburg-Nord}

Duisburg-Nord industrial landscape park is located in the city of Duisburg (Figure 1). The park is situated on the site of the Thyssen Steelworks manufacturing plant which ceased to exist in 1985. Instead of being closed the steelworks was transformed into a park as part of the IBA project while maintaining industrial components and allowing free growth of vegetation, which is much more practical and cost-effective than process of de-industrialization. The project was an attempt to rehabilitate an area that has had serious 
problems with environmental, economic and social decline during the past few decades. The park covers more than 500 acres of mostly open space. Here visitors can see: blast furnaces, adapted Gasometer (converted into the largest diving center in Europe with artificial reef and sunken yacht), former ore storage bunkers containing alpine climbing gardens, large square Piazza Metallica (Figure $2 \mathrm{C}$ ) (where performances and festivals are held), gardens Sintergarten and Bunkergartens, large metal pipes passing through walls which are used as slides for children and so on. Within the park there are visitor's center and a restaurant. The steelworks are illuminated at night with colorful lights that symbolize the time when it was active (Figure 2D) (http://courses.umass.edu/latour/ Germany/tnickerson/projectdescription.html).

\section{Recultivation through creation of tips and development of tip tourism}

Recultivation is a process whereby a part of a dump is brought back to the state of land similar to the one before the excavation. In this way, the negative impact of the excavation of overburden and coal is lessened. The recultivation process is a legal obligation, which is to be implemented according to a recultivation project (Haigh, 2006).

Tips (Bergehalden) are artificial hills that were formed by accumulation of mining material. These artificial mountains are visible for kilometers, and are typical part of landscape in coal mining regions such as Ruhr, Aachen and Saar. The first part of the word berge does not mean mountain or peak in topographic sense, but it is a miner's expression for waste rock. An increasing amount of waste material generated by mining gave rise to need to accumulate more waste on smaller areas. Transport of this material over conveyor belts led to formation of conical hills. The first generation of hills was mainly composed of several overlapping cones. The second generation were terraced flattened 'mountains' with rough contours. The third generation is the result of the recultivation - forested hills adapted for so-called 'Tip tourism' (Figure 3) (Bottmeyer, 2011).

\section{Example of Hoheward tip}

Hoheward tip is located in the north of Ruhr, and is one of the most attractive new tips. It rose from heaps of mining waste material from several mines, and is situated between the cities of Herten and Recklinghausen. Together with Hoppenbruch tip it forms one of the largest landscape scenes of this type in Europe. The highest point of the tip is located at an elevation of $152.5 \mathrm{~m}$ above sea level. The tips are part of the Industrial heritage trail and Hoheward Landscape Park. On top of Hoheward there are Obelisk, Sundial and a
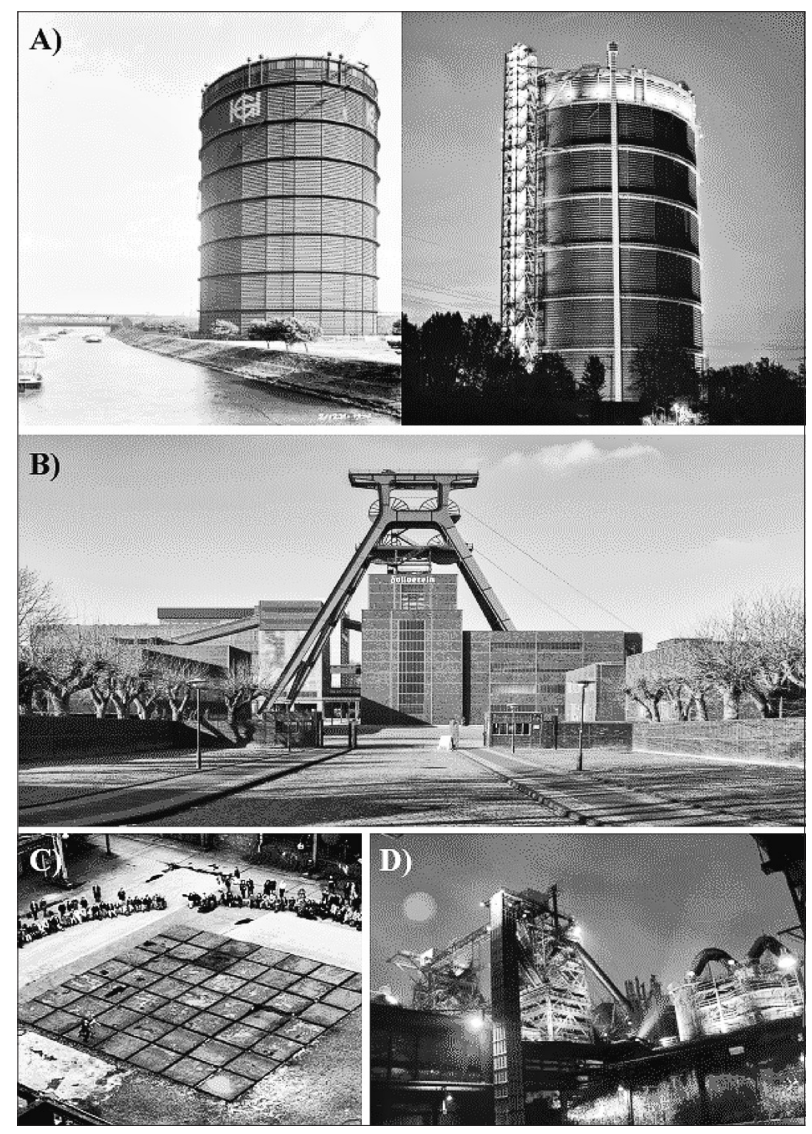

Figure 2.

(A) Gasometer in Oberhausen before (left) ( www. gasometer.de/en/the-gasometer/technology) and after transformation (right) (www.einzigartige-museen. de/2012/o8/gasometer-oberhausen/);

(B) Pithead tower in Zollverein (http:// http://www.zollverein.de/uploads/ assets/5379f8c6695498688fo00038/Zollverein_ UNESCO_World_Heritage_Site_image_brochure_2014. pdf);

(C) Piazza Metallica (http://courses.umass.edu/latour/ Germany/tnickerson/projectdescription.html);

(D) Industrial landscape park Duisburg-Nord

(http://courses.umass.edu/latour/Germany/tnickerson/ projectdescription.html)

1. Generation

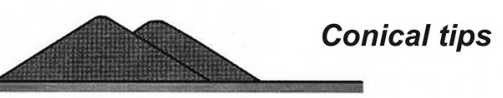

2. Generation
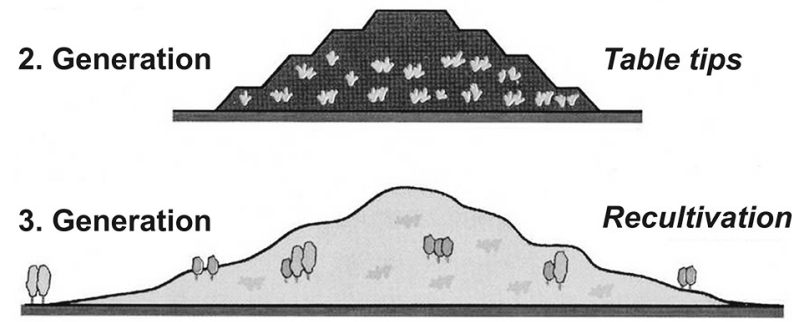

Figure 3. Three generations of tips

Source adapted from: Bottmeyer, 2011 
Horizontal observatory. Another attraction is the 165 $\mathrm{m}$ long Dragon bridge intended for pedestrians and cyclists (Bottmeyer, 2011).

\section{The effects of industrial heritage tourism development in the Ruhr area}

When talking about transformations that have occurred as a result of the development and activity of tourism in a specific area, it should be noted that this is not only about changes in the physical space. The impacts of tourism are complex and there are environmental, socio-cultural and economic effects of tourism (Stojanović, 2006). Tourism potentials seem to be easy to establish by local actors, often in combination with other regional initiatives and European funding (Jones, Munday, 2001). Touristic potentials which can be modified by the mining include technological heritage, infrastructure, production facilities and housing (Marot, Harfst, 2012).

\section{Environmental effects}

The main determinant factors in the success of a region are the fulfilment of the conditions for a good social and economic environment (Đukičin, et al., 2014). The mining industry cause a significant impact on the environment and it occurs within all the technological exploitation and processing stages (Fodor, 2010).

Industrial heritage tourism can have a positive impact on protection and improvement of the environment. The development of this type of tourism has spurred the investments of public sector in urban areas, as well as cleaning of contaminated and neglected land in former industrial areas (Lane, et al., 2013).

Examples of environmental effects in the Ruhr are aforementioned cleaning of the Emscher River, greening of industrial complexes (gardens) and artificial hills - tips. This process created conditions for devel- opment of new ecosystems in places where there was virtually no nature.

\section{Economic effects}

Sites of industrial heritage, like most tourist destinations, get bulk of their revenue from ticket sales, which can be considered primary source of income. The secondary sources of revenue include sales of food, beverages, travel expenses and accommodation (Lane et al., 2013).

Employing local people and their involvement in the development of tourism offer has a significant economic impact. Many communities in Ruhr had benefited from the development of tourism industry, especially there has been an increase in employment, which was very important for the region who had serious issues with the decline of industry and growing numbers of unemployed since the 50's.

Effects of industrial heritage tourism in the Ruhr are evident in the increase of overnight stays by $60.6 \%$ during the period 1990-2009. Certain cities like Bottrop, Dortmund and Essen marked growth rates of over $50 \%$, which supports the fact that relatively unattractive industrial cities with modest tourism offer had turned into interesting destinations for tourists, and consequently generate greater revenues from tourism (Table 1).

\section{Socio-cultural effects}

One of the typical socio-cultural benefits that industrial areas have from tourism is the recognition and celebration of the past, which gives meaning to the lives and memories of older residents, and connects their lives with the present and the future. Increase of local pride has influence on greater attachment to a place and on local identity (Lane, et al., 2013).

Another important benefit, concerning the cultural effects of industrial heritage tourism development

Table 1. Overnight stays statistics for selected cities of the Ruhr region for the period 1990-2009

\begin{tabular}{|c|c|c|c|c|c|c|c|c|}
\hline & \multicolumn{3}{|c|}{ Overnight stays } & \multirow{2}{*}{$\begin{array}{c}\text { Increase } \\
1990- \\
2009\end{array}$} & \multirow{2}{*}{$\begin{array}{c}\text { Average } \\
\text { duration of stay } \\
2009 \text { (days) }\end{array}$} & \multirow{2}{*}{$\begin{array}{c}\text { Share of } \\
\text { foreign } \\
\text { guests } 2009\end{array}$} & \multirow{2}{*}{$\begin{array}{c}4^{*} \\
\text { hotels }\end{array}$} & \multirow{2}{*}{$\begin{array}{c}5^{*} \\
\text { hotels }\end{array}$} \\
\hline & 1990 & 2000 & 2009 & & & & & \\
\hline Bottrop & 37,900 & 66,000 & 73,300 & $93.4 \%$ & 1.7 & $29.4 \%$ & 1 & 0 \\
\hline Dortmund & 445,800 & 597,000 & 749,300 & $68.1 \%$ & 1.5 & $20.2 \%$ & 9 & 0 \\
\hline Duisburg & 261,400 & 322,300 & 361,600 & $38.3 \%$ & 2.0 & $16.5 \%$ & 3 & 0 \\
\hline Essen & 674,100 & 910,600 & $1,067,800$ & $58.4 \%$ & 2.1 & $16.9 \%$ & 12 & 1 \\
\hline Hamm & 104,300 & 113,300 & 123,200 & $18.1 \%$ & 1.7 & $17.5 \%$ & 2 & 0 \\
\hline The Ruhr & $3,598,300$ & $4,677,700$ & $5,777,500$ & $60.6 \%$ & 1.9 & $16.1 \%$ & - & - \\
\hline \multicolumn{9}{|c|}{ Compared to: } \\
\hline Düsseldorf & $2,091,900$ & $2,434,800$ & $3,222,000$ & $53.9 \%$ & 1.7 & $37.6 \%$ & 26 & 2 \\
\hline Köln & $2,589,200$ & $3,066,400$ & $4,133,244$ & $59.6 \%$ & 1.8 & $32.3 \%$ & 25 & 3 \\
\hline
\end{tabular}

Source adapted from: Keil, Wetterau, 2013 
in Ruhr, is promotion of creativity through various forms of modern art (installations, exhibitions, etc.).

It is important to emphasize the fact that without the development of tourism it would not be possible to preserve the industrial heritage that would be left to oblivion and the ravages of time.

\section{Conclusion}

Tourism has proven to be an effective geospace transformation tool, especially in the case of industrial heritage. Abandoned and forgotten industrial complexes were given new purpose and meaning which contributed to local economy, strengthened the local (regional) identity, and affected the overall development of tourism.

Ruhr area in western part of Germany is one of the most representative projects of adaptation of industrial facilities into cultural facilities and recreation sites. It is a good example of sustainable development, considering the fact that tourism in this region served as an instrument of revitalization and conservation of industrial heritage. The locations of mine pits, factories etc. were turned into galleries, music venues, recreation areas, bike paths, green sustainable surfaces. The former industrial region changed its image and became a significant tourist region with emphasis on culture and recreation tourism based on industrial heritage.

Transformation of the Ruhr through industrial heritage tourism served as a model for the ERIH I project (European Route of Industrial Heritage). The goal of the project was to create a brand for industrial heritage tourism, which could be used across Europe. This initiative demonstrates how successful and effective the IBA program was. Also, experience from Germany could be applied to similar areas and regions across European continent.

\section{Acknowledgement}

This work is supported by the Ministry of Education, Science and Technological Development, Republic of Serbia (grants 176020 and 47024).

\section{References}

Bottmeyer, M. 2011. Land Management of Former Industrial Landscapes in the Economic Metropolis Ruhr. FIG Working Week.

Cho, M., Shin, S. 2014. Conservation or economization? Industrial heritage conservation in Incheon, Korea, Habitat International, 41, 69-76.

Đukičin, S., Milanković, J., Đorđević, J. 2011. Contemporary Business Trends and Industrial Trans- formation in Slovenia on the Examples of Maribor and Celje. Geographica Pannonica, 15, 3, 81-89.

Đukičin, S., Đorđević, J., Milanković, J. 2014. Spatial and social changes caused by the continuous exploitation of lignite in the Kolubara lignite basin, Serbia. Acta geographica Slovenica, 54, 1, DOI: 10.3986/AGS54102, article in press

Edwards, J., Llurdes, J. 1996. Mines and quarries: Industrial heritage tourism. Annals of Tourism Research, 23, 341-363.

Fischer, W., Stranz, S. 2011. Analysis of an exemplary post-mining regeneration - a potential implementation in Styria/Austria. Grazer Schriften der Geographie und Raumforschung, 26, 155-168.

Fodor, D. 2010. Mining industry and environment. Revista Minerol, 16, 8, 2-12.

Garača, V., Trifković, A., Curčić, N., Vukosav, S. 2014. Aspects of industrial heritage Tourism: Case of Novi Sad. Revista de cercetare si interventie sociala, 44, 181-198.

Haigh, M. J. 2006. Degradation of Reclaimed Lands Previously Disturbed by Coal Mining in Wales: Causes and Remedies. Land Degradation \& Development, 3, 3, 169-180.

Halewood, C., Hannam, K. 20o1. Viking heritage tourism: Authenticity and commodification. Annals of Tourism Research, 28, 3, 565-580.

Hospers, G. 2002. Industrial heritage tourism and regional restructuring in the European Union. European Planning Studies, 10, 3, 398-404.

Jahić, E., Dragin, A., Romelić, J. 2014. Industrial Heritage in Tuzla Canton Tourist Offer. Turizam, 18, 2, 44-58.

Jones, C., Munday, M. 2001. Blaenavon and United Nations World Heritage Site Status: Is Conservation of Industrial Heritage a Road to Local Economic Development? Regional Studies, 35, 6, 585-59o.

Keil, A., Wetterau, B. 2013. Metropolis Ruhr. A Regional Study of the New Ruhr. Regionalverband Ruhr, Essen, 105 pp.

Kretschmann, J. 2013. Stakeholder orientated sustainable land management: The Ruhr Area as a role model for urban areas. International Journal of Mining Science and Technology, 23, 659-663.

LaBelle, M. J. 2001. Emscher Park, Germany - Expanding the Definition of a "Park“. The George Wright Society Forum, 18, 3.

Lane, B., Kastenholz, E., Lima, J., Majewsjki, J. 2013. Industrial Heritage and Agri/Rural Tourism in Europe. European Parliament, Brussels, 141 pp.

Maksin Mićić, M. 2007. Tourism and space. Singidunum University, Belgrade, $380 \mathrm{pp}$.

Marot, N., Harfst, J. 2012. Post-mining potentials and redevelopment of former mining regions in Central Europe - Case studies from Germany and Slovenia. Acta geographica Slovenica, 52, 1, 99-119. 
Mitchneck, B. 1998. The heritage industry Russian style: The case of Yaroslavl. Urban Affairs Review, $34,28-52$.

Petrović, T. 2013. Museums and Workers: Negotiating industrial heritage in the former Yugoslavia. Narodna umjetnost-Croatian Journal of Ethnology and Folklore Research, 50, 1, 96-120.

Prossek, A. 2006. Culture through transformation transformation through culture. Industrial Heritage in the Ruhr Region - the example of Zeche Zollverein. Heritage and Media in Europe, 3, 239248.

Ravbar, M., Bole, D., Nared, J. 2005. A creative milieu and the role of geography in studying the competitiveness of cities: the case of Ljubljana. Acta Geographica Slovenica, 45, 2, 7-34.

Stojanović, V. 2006. Sustainable development of tourism and environment. Faculty of Sciences, Department of Geography, Tourism and Hotel Management, Novi Sad, 242 pp.
Trettin, L., Neumann, U., Zakrzewski, G. 2011. Essen and the Ruhr Area - The European Capital of Cultural 2010: Development of tourism and the role of SMEs. ERSA conference papers ersa10p357, European Regional Science Association.

Xie, F.P. 2006. Developing industrial heritage tourism: A case study of the proposed jeep museum in Toledo, Tourism Management, 27, 6, 1321-1330.

$\infty$

http://courses.umass.edu/latour/Germany/tnickerson/projectdescription.html

www.einzigartige-museen.de/2012/o8/gasometeroberhausen/

www.gasometer.de/en/

www.gasometer.de/en/the-gasometer/technology

www.zollverein.de/uploads/ assets/5379f8c6695498688foooo38/Zollverein UNESCO_World_Heritage_Site_image_ brochure_2014.pdf 